\title{
Better Gel Resolution and Longer cDNAs Increase the Precision of Differential Display
}

\author{
L. Averboukh, S.A. Douglas ${ }^{1}$, S. Zhao, K. Lowe ${ }^{2}$, J. Maher ${ }^{2}$ and A.B. Pardee \\ Dana-Farber Cancer Institute, Boston, MA; ${ }^{1}$ SmithKline Beecham Pharmaceuticals, \\ King of Prussia, PA; and ${ }^{2}$ Genomyx, Foster City, CA, USA
}

BioTechniques 20:918-921 (May 1996)

The differential display technique introduced in 1992 has become a widely used method for the rapid identification of differentially expressed genes in a variety of eukaryotic systems (4). In the past three years, technical modifications have reduced the redundancy of anchored primers, decreased the number of reverse transcription reactions needed, increased reproducibility, reduced the incidence of false positives and increased the overall efficiency of the method (5).

The original method separates cDNAs on a denaturing polyacrylamide gel. However, conventional DNA sequencers sometimes do not provide adequate gel resolution, resulting in the inadvertent isolation of several cDNAs from what appears to be a single band. These cDNAs may represent independent cDNA fragments of the same or very similar molecular weight (2), separated strands of a unique doublestranded cDNA molecule with or without Taq DNA polymerase-mediated addition of 3 '-terminal adenosine nucleotide (1), truncated polymerase chain reaction (PCR)

Figure 1. Differential display run on a GenomyxLR DNA Sequencer versus a conventional DNA sequencer. $\mathrm{LNCaP-FGC} \mathrm{prostate} \mathrm{cancer} \mathrm{cells} \mathrm{were}$ subjected to 4 days of androgen deprivation followed by addition of synthetic androgen R1881 to the medium. Total RNA samples were collected after $0,1,5,10,25,50$ and $75 \mathrm{~h}$ of androgen treatment (lanes $1-7$, respectively). Differential display was performed with the following primers: $\mathrm{H}_{-11} \mathrm{C}\left(5^{\prime}\right.$ AAGCTTTTTTTTTTTC-3') and HAP-9 (5'-AAGCTTCATTCCG- $3^{\prime}$ ) (GenHunter, Brookline, MA, USA), where $\mathrm{H}$ represents a HindIII recognition site (AAGCTT). PCR conditions: $94^{\circ} \mathrm{C}, 30 \mathrm{~s} ; 40^{\circ} \mathrm{C}, 2 \mathrm{~min} ; 72^{\circ} \mathrm{C}, 30 \mathrm{~s}(40 \mathrm{cy}-$ cles). DNA polymerase: 1 unit of AmpliTaq ${ }^{\circledR}(5 \mathrm{U} / \mu \mathrm{L})$ (Perkin-Elmer, Norwalk, CT, USA). Isotope: $1 \mu \mathrm{Ci}$ of $[\alpha-33 \mathrm{P}] \mathrm{dATP}(2000 \mathrm{Ci} / \mathrm{mmol})$ (Du Pont NEN, Boston, MA, USA). PCR machine: GeneAmp ${ }^{\circledR}$ PCR System 9600 (Perkin-Elmer). Panels A: 6\% HR-1000 ${ }^{\mathrm{TM}}$ denaturing gel (Genomyx) run on a GenomyxLR DNA Sequencer gel size $60 \times 32 \mathrm{~cm}$ (Genomyx) and $6 \%$ denaturing Sequagel (National Diagnostics, Atlanta, GA, USA) run on a conventional DNA sequencer, gel size $30 \times 40 \mathrm{~cm}$, left and right panels, respectively. Run conditions for Genomyx DNA Sequencer: $50^{\circ} \mathrm{C}, 3000 \mathrm{~V}, 100 \mathrm{~W}$, $3 \mathrm{~h}$; for conventional sequencer: $60 \mathrm{~W}$ constant power, $1500 \mathrm{~V}, 3.5 \mathrm{~h}$. The arrowheads indicate a differentially expressed 360-base cDNA fragment. Panels B: $4.5 \%$ HR-1000 denaturing gel run on a GenomyxLR DNA Sequencer and $4.5 \%$ denaturing Sequagel run on a conventional sequencer, left and right panels, respectively. Run conditions are the same as in part A. Arrowheads indicate a differentially expressed 360-base cDNA fragment.

products of a unique cDNA (unpublished data) and fragments representing a unique cDNA with multiple polyadenylation sites (3). Here we report the use of a new programmable DNA sequencer, called the GenomyxLR ${ }^{\mathrm{TM}}$ (Genomyx, Foster City,

A

122345567

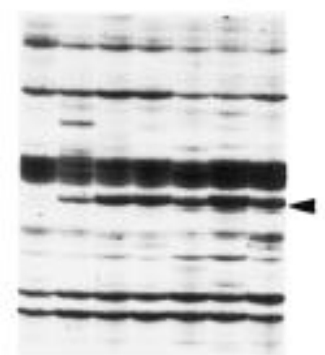

B $\begin{array}{lllllll}1 & 2 & 3 & 4 & 5 & 6 & 7\end{array}$

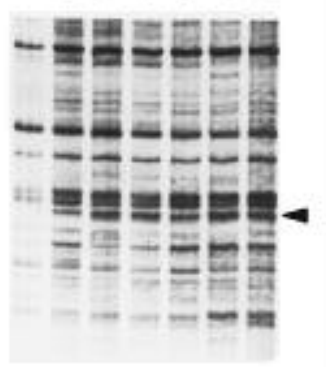

122345667

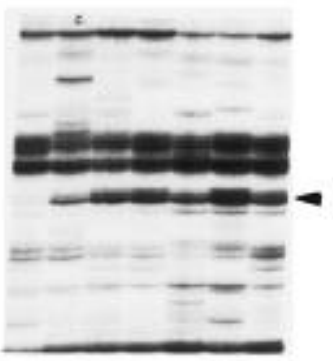

$\begin{array}{lllllll}1 & 2 & 3 & 4 & 5 & 6 & 7\end{array}$

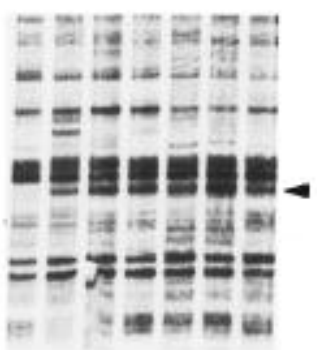




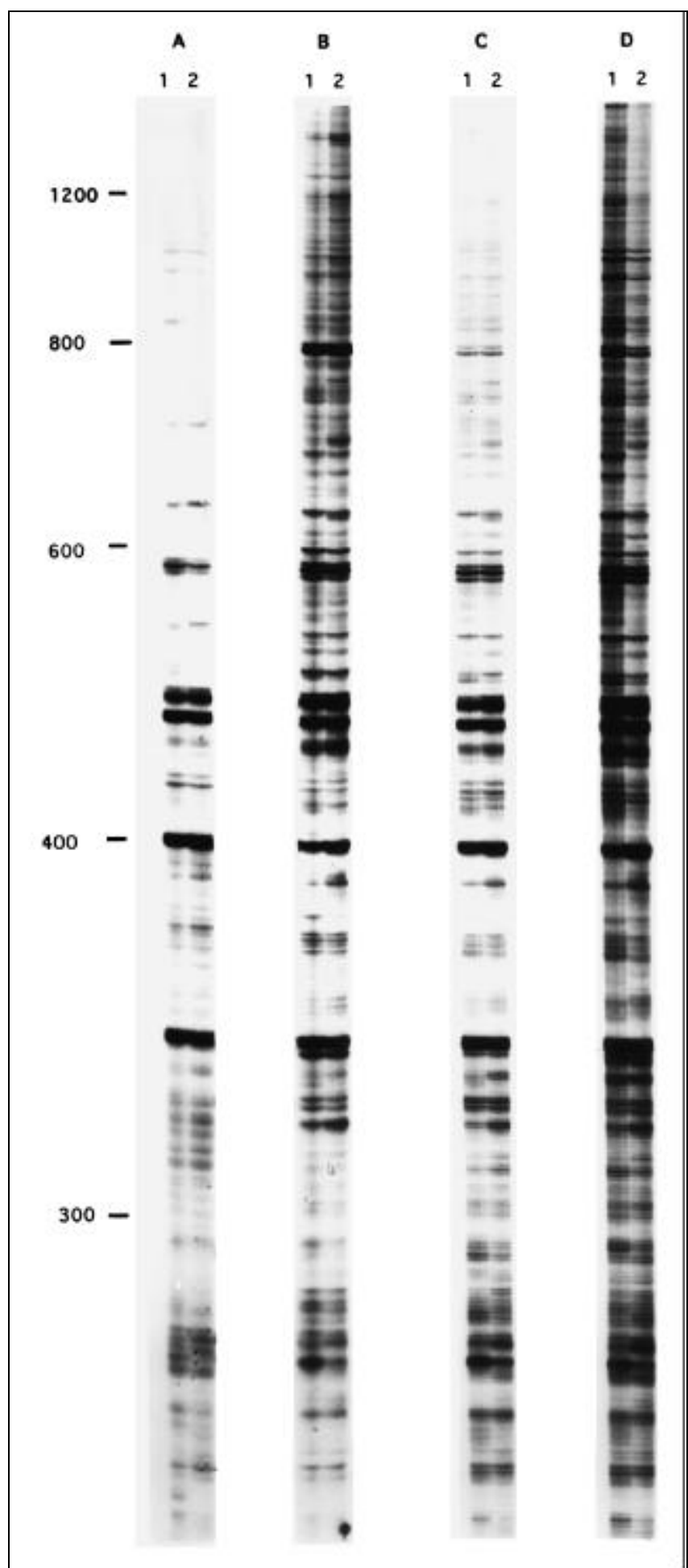

Figure 2. Differential display of long cDNA products. LNCaP-FGC cells were subjected to 4 days of androgen deprivation followed by addition of synthetic androgen R1881 to the medium. Lanes 1 and 2 are total RNA samples collected after 0 and $75 \mathrm{~h}$ of androgen treatment. Differential display was performed with $\mathrm{H}-\mathrm{T}_{11} \mathrm{C}$ and HAP-14 (5'-AAGCTTGGAGCTT-3') primers (GenHunter). DNA polymerase: 1 unit of AmpliTaq (5 U/ $\mu \mathrm{L}$ ) (PerkinElmer); isotope: $1 \mu \mathrm{Ci}$ of $[\alpha-33 \mathrm{P}] \mathrm{dATP}(2000 \mathrm{Ci} / \mathrm{mmol})$ (Du Pont NEN). PCR machine: GeneAmp PCR System 9600. (A) PCR conditions: $94^{\circ} \mathrm{C}, 30 \mathrm{~s}$; $40^{\circ} \mathrm{C}, 2 \mathrm{~min} ; 72^{\circ} \mathrm{C}, 30 \mathrm{~s}$ ( 40 cycles $)$. Final cold dNTP concentration is $2 \mu \mathrm{M}$. (B) PCR conditions: $94^{\circ} \mathrm{C}, 30 \mathrm{~s} ; 40^{\circ} \mathrm{C}, 2 \mathrm{~min} ; 72^{\circ} \mathrm{C}, 30 \mathrm{~s}(40$ cycles). Final cold dNTP concentration is $20 \mu \mathrm{M}$. (C) PCR conditions: $94^{\circ} \mathrm{C}, 30 \mathrm{~s} ; 40^{\circ} \mathrm{C}, 2$ min; $72^{\circ} \mathrm{C}, 60 \mathrm{~s}$ ( 40 cycles). Final cold dNTP concentration is $2 \mu \mathrm{M}$. (D) PCR conditions: $94^{\circ} \mathrm{C}, 30 \mathrm{~s} ; 40^{\circ} \mathrm{C}, 2 \mathrm{~min} ; 72^{\circ} \mathrm{C}, 90 \mathrm{~s}$ ( 40 cycles). Final cold dNTP concentration is $2 \mu \mathrm{M}$. MW is a 100 -bp DNA marker (Life Technologies). 
CA, USA), for differential display resulting in both better resolution of cDNA bands and better separation of large cDNA fragments. This sequencer allows for the independent control of voltage and temperature. Therefore, gels may be run at higher temperatures, which, together with a read-length double that of conventional gels, helps to increase band separation. The use of single-base anchored primers and longer arbitrary primers (6), combined with the use of a $4.5 \%$ gel run on the improved sequencer, results in higher resolution of bands, thereby decreasing the likelihood of isolating multiple cDNAs from a single band (Figure 1). When a high resolution on a denaturing gel system is achieved, one should expect to see, instead of a single band, at least two bands representing different strands of the same cDNA. If more than two bands are seen, they are likely to represent contaminant PCR products. Thus, higher gel resolution can help to unmask overlapping fragments.

Another issue surrounding the ability of differential display involves the PCR-mediated reamplification of large cDNA fragments, greater than $500 \mathrm{bp}$ in size. Longer cDNA products are advantageous as they can be more easily confirmed by Northern blot analysis and because more radioactive nucleotides will be incorporated into the probe as compared with shorter cDNA fragments. Furthermore, longer cDNAs may hybridize to target mRNA with a higher affinity and they provide more sequence information. Long cDNAs over $1 \mathrm{~kb}$ may be obtained by either increasing the dNTP concentration to $20 \mu \mathrm{M}$, in combination with PCR conditions standard for the method $\left(94^{\circ} \mathrm{C}, 30 \mathrm{~s} ; 40^{\circ} \mathrm{C}, 2 \mathrm{~min} ; 72^{\circ} \mathrm{C}\right.$, $30 \mathrm{~s}$ ), or by increasing the elongation time to $90 \mathrm{~s}$ or more at $2 \mu \mathrm{M}$ dNTP concentration (Figure 2). The combination of $20 \mu \mathrm{M} \mathrm{dNTP}$ and $90 \mathrm{~s}$ elongation time (annealing temperature $40^{\circ} \mathrm{C}$ ) resulted in amplification of nonspecific PCR products. Although larger cDNAs may be produced by increasing either dNTP concentration or elongation time, increasing the latter is recommended because an increase in the former can lead to mispriming at nontarget sites and subsequent extension of misincorporated nucleotides. Therefore, increasing extension time while maintaining the "standard" dNTP

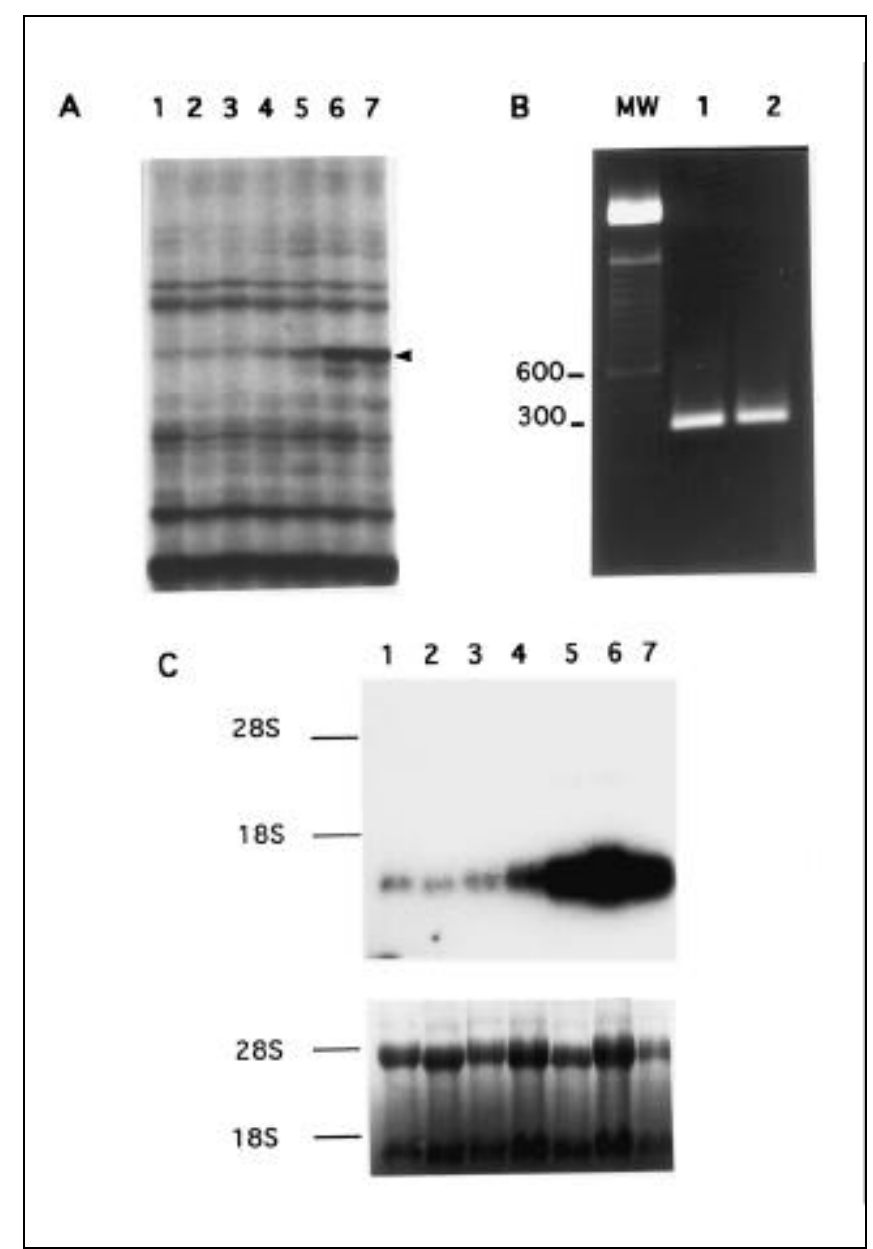

Figure 3. Isolation of differentially expressed cDNA from a sequencing gel, reamplification and Northern blot confirmation. (A) $4.5 \%$ denaturing differential display gel of LNCaP-FGC prostate cancer cells subjected to 4 days of androgen deprivation followed by addition of synthetic androgen R1881 to the medium. Total RNA samples were collected after $0,1,5,10,25$, $50,75 \mathrm{~h}$ of androgen treatment (lanes $1-7$, respectively). Differential display was performed with $\mathrm{H}^{-\mathrm{T}_{11} \mathrm{~A}}$ (5'-AAGCTTTTTTTTTTTA-3') and HAP-13 (5'-AAGCTTCGGCATA- $3^{\prime}$ ) primers. The arrowhead indicates differentially expressed cDNA. (The quality of the print is inferior due to the loose contact of the film with the gel). (B) Reamplified differentially expressed cDNA fragments cut from differential display gel lanes 6 and 7 (lanes 1 and 2, respectively) run on a $0.8 \%$ agarose gel. MW is a 100 -bp DNA marker (Life Technologies). (C) Northern blot analysis of differentially expressed cDNA (upper panel) in the LNCaP-FGC cells total RNA samples originally used for differential display. Lanes 1-7 are cells hormone treated for 0, 1, 5, 10, 25, 50 and $75 \mathrm{~h}$. Twenty micrograms of total RNA from each time point were analyzed. Positions of $28 \mathrm{~S}$ and $18 \mathrm{~S}$ RNA are indicated. A negative of ethidium bromide staining of total RNA samples is shown as control for equal loading (lower panel). 
concentration will help preserve overall PCR fidelity and specificity. Long cDNAs, which tend to crowd near the top of "conventional" differential display gels, are more easily resolved on a $4.5 \%$ polyacrylamide gel run on the improved GenomyxLR DNA sequencer.

This new sequencing system combines an improved sequencer, power supply and gel drier in a single unit. Gels are dried directly on the glass plate. This procedure provides accurate band excision by allowing the autoradiogram to serve as a template when placed directly underneath the dried gel. Drying the gel directly on the glass plate rather than transferring it onto paper does not alter the cDNA extraction procedure. cDNAs can still be cut out from the gel, reamplified and confirmed by Northern blot (Figure 3).

In conclusion, achieving higher resolution of cDNAs in differential display increases the efficiency of the method since poor band separation often causes technical difficulties in cloning differentially expressed genes. The described improvements also allow the display of longer cDNAs, which increases the probability of acquiring more sequence information for more rapid and efficient gene identification.

\section{ACKNOWLEDGMENTS}

We thank Dr. Peng Liang for helpful discussions and Dr. Christoph Ahlers for careful review of the manuscript.

\section{REFERENCES}

1.Bauer D., H. Muller, J. Reich, H. Riedel, V. Ahrenkiel, P. Warthoe and M. Strauss. 1993. Identification of differentially expressed mRNA species by an improved display technique (DDRT-PCR). Nucleic Acids Res. 21:4272-4280.

2.Callard, D., B. Lescure and L. Mazzolini. 1994. A method for the elimination of false positives generated by the mRNA differential display. BioTechniques 16:1096-1103.

3.Liang P., L. Averboukh, K. Keyomarsi, R. Sager and A.B. Pardee. 1992. Differential display and cloning of messenger RNAs from human breast cancer versus mammary epithelial cells. Cancer Res. 52:69666968.

4.Liang, P. and A.B. Pardee. 1992. Differential diplay of eukaryotic messenger RNA by means of the polymerase chain reaction. Science 257:967971.

5.Liang, P. and A.B. Pardee. 1995. Recent advances in differential display. Curr. Opinion Immunol. 7:274-280.

6.Liang, P., W. Zhu, X. Zhang, Z. Guo, R. O'Connell, L. Averboukh, F. Wang and A.B. Pardee. 1994. Differential display using one-base anchored oligo-dT primers. Nucleic Acids Res. 22:5763-5764.

Address correspondence to Lidia Averboukh, Division of Cell Growth and Regulation, Dana-Farber Cancer Institute, 44 Binney Street, Boston, MA 02115, USA. 